\title{
Loess encounters of three kinds: Charles Lyell talks about, reads about, and looks at loess
}

\author{
Ian Smalley ${ }^{1,}{ }^{*}$, Holger Kels ${ }^{2}$, Tivadar Gaudenyi ${ }^{3}$, Mladjen Jovanovic ${ }^{4}$ \\ ${ }^{1}$ Giotto Loess Research Group, Geography Department, University of Leicester, Leicester LE1 7RH, UK, \\ e-mail: ijsmalley@gmail.com \\ ${ }^{2}$ Geography Department, RWTH Aachen University, Templergragen 55, 52056 Aachen, Germany, \\ e-mail: holger.kels@geo.rwth-aachen.de \\ ${ }^{3}$ Geographical Institute 'Jovan Cvijic', Serbian Academy of Sciences \& Arts, 11000 Belgrade, Serbia, \\ e-mail: t.gaudenyi@gi.sanu.ac.rs \\ ${ }^{4}$ Physical Geography, Faculty of Sciences, University of Novi Sad, 21000 Novi Sad, Serbia, \\ e-mail: mladjen.jovanovic@dgt.uns.ac.rs \\ *corresponding author
}

\begin{abstract}
Charles Lyell (1797-1875) was an important loess pioneer. His major contribution was to distribute information on the nature and existence of loess via his influential book 'The Principles of Geology'. He was obviously impressed by loess when he encountered it; the initial encounter can be split into three phases: conversations about loess; confronting the actual material in the field; and reading about loess in the literature. Detail can be added to an important phase in the scientific development of the study of loess. Significant events include conversations with Hibbert in 1831, conversations and explorations with von Leonhard and Bronn in 1832, the opportunity to include a section on loess in vol. 3 of 'Principles' for publication in 1833, a substantial Rhineland excursion in 1833, the reporting of the results of this excursion in 1834, discussions at the German Association for the Advancement of Science meeting in Bonn in 1835. Of all the people encountered perhaps H.G. Bronn was the most significant. Lyell eventually listed eleven people as relevant to the loess writings: Bronn, von Leonhard, Boue, Voltz, Steininger, Merian, Rozet, Hibbert, Noeggerath, von Meyer, Horner - of these Bronn, von Leonhard, Hibbert and Horner appear to have been the most significant, viewed from 2015.
\end{abstract}

Keywords: Loess, loess history, Charles Lyell, Bronn and Horner

\section{Introduction}

The study of loess began in Heidelberg in 1824. When Karl Caesar von Leonhard published his book 'Charakteristik der Felsarten' the study of loess was launched (Jovanovic et al., 2014). Von Leonhard described loess and referred to it on his list of defineable ground materials. It had been talked about before and there was a variety of names in use but von Leonhard gave the required authority and definition and loess was launched into the world of geoscience.
In 1832 Charles Lyell was in the process of compiling his book 'The Principles of Geology' in Heidelberg. In 1832 he was working on vol. 3, which would eventually be published in 1833, completing the first edition. Lyell met interesting people in Heidelberg, including von Leonhard and H.G. Bronn. Lyell was impressed by the loess and included an interesting section in vol. 3 about the Rhine valley deposits (Smalley et al., 2015). This was the key 'spreading-the-word'-moment and with the successful sale of the 'Principles' came a widespread appreciation of the existence and nature of loess. 
This is an outline of events which deserves to be developed and enlarged upon.

The aim of the present paper is to explore Charles Lyell's early encounters with loess, to attempt to identify individuals who were involved in these early discussions, and to demarcate Lyell's very first experiences of loess: in conversation, in actual field observations, and in the literature of the time.

\section{Conversations, observations, and literature}

In September 1831 Lyell visited Samuel and Charlotte Hibbert at their house in Edinburgh, to talk about geology and in particular the Eifel and Rhine volcanoes: "Never having heard of that beautiful map which Von Oeynhausen lent me, they lost much time in constructing a map, which Hibbert did trigonometrically. They have really collected both rocks and shells, and worked and sketched to great effect. In the 'loess' descending from Kruft to Andernach, they found a vast number of land shells, which seem to indicate a modern date to that formation." (Letter from Lyell to Mary Horner dated 8 September 1831; see Lyell, 1881).

The Hibberts spent many months in the volcanic regions and the result was a definitive book (Hibbert, 1832) which included a fairly detailed section on loess - possibly the first generally available description of loess in English. Lyell spent several days in the same region at about the same time.

1831 was a year of some consequence in the geological world. At around the same time as Lyell was in the Eifel Adam Sedgwick and Charles Darwin were in Wales where Darwin was learning to be a geologist. When he got home he found a letter from Robert FitzRoy inviting him to go on a geological adventure. He went, of course, and took with him a copy of vol. 1 of the 'Principles'. In 1831 the British Association for the Advancement of Science (modelled on the Gesellschaft Deutsche Naturforscher und Ärzte) held its inaugural meeting in York. There was a large geological presence with R.I. Murchison being elected president of Section C Geology.

In 1831 the first Wollaston medal was awarded by the Geological Society of London to William Smith; subsequently various loess-related people were recognized: Ami Boue in 1847, von Meyer in 1858, Studer in 1879, Bronn in 1861, Murchison in 1864, Bonney in 1889, and of course Lyell himself in 1866.

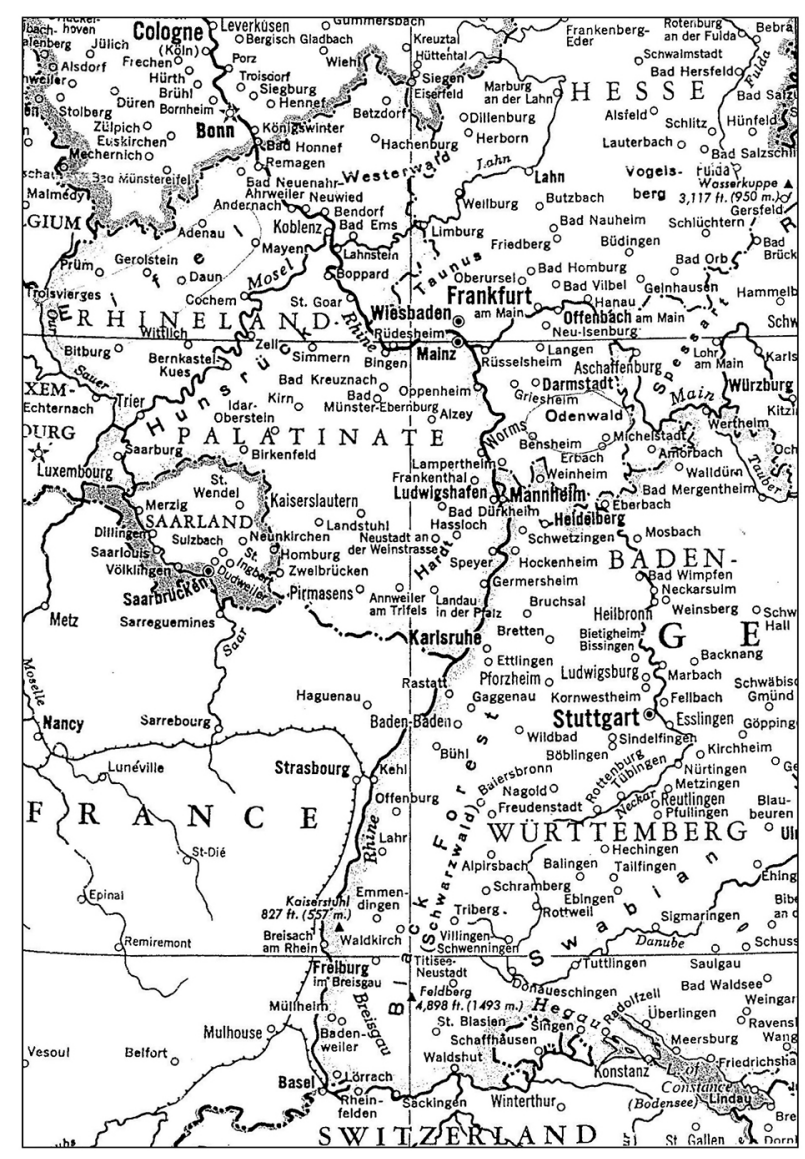

Fig. 1. Map of the Rhine 'from Basle to Bonn' and parts adjoining, to complement maps in Wilson (1972) and Smalley et al. (2015).

At Heidelberg, in 1832, Lyell met the naturalists von Leonhard and Bronn and examined their collections. He also went on a field trip with von Leonhard to examine the superficial deposit, peculiar to the Rhine valley (Fig. 1), called loess. Wilson (1972) wrote: "Lyell found that the loess contained many of both land shells and freshwater shells as fossils. He thought that this unstratified earth must have been deposited by a great flood occasioned by the sudden release of the waters of a great lake like the Lake of Constance (Bodensee). Lyell had frequently observed the geological effects of large scale floods and loess was a unique deposit, puzzling to account for".

Lyell met Phillippe-Louis Voltz who was chief mining engineer of the Strasburg district and Bernhard Studer, the Swiss geologist. Studer (Fig. 2) was a very considerable geologist, he was awarded the Wollaston medal in 1879, and makes an appearance in the 'Principles': "I am informed by M. Studer, that the loess does not extend into Switzerland, but the Kaiserstuhl, a group of volcanic hills, standing almost in the middle of the plain of the Rhine, south 


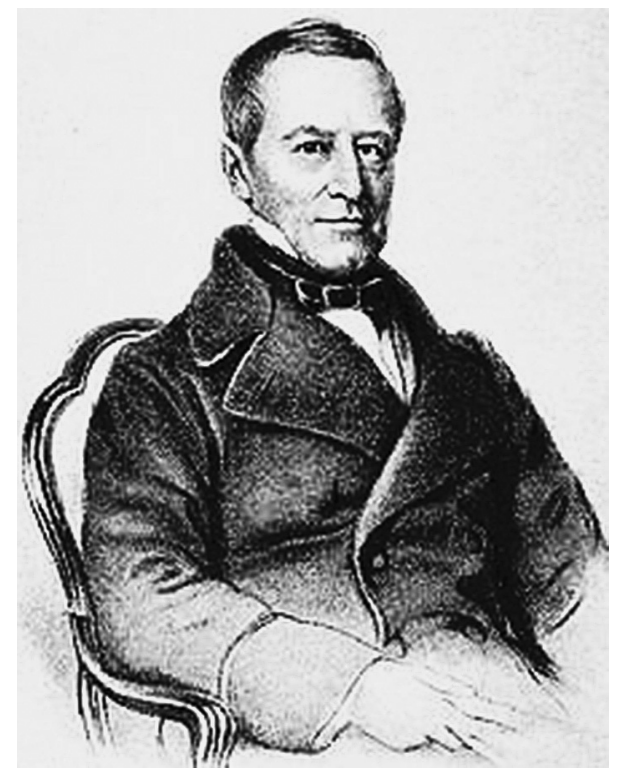

Fig. 2. Bernhard Studer (1794-1887). Swiss geologist; conversations with Lyell in 1832; awarded Wollaston medal 1879.

of Strasburg, is covered with it to a great height; and I have seen it in large masses near the base of the Vosges, on the left side of the plain of the Rhine, near Strasburg, and on the right side, at the base of the mountains of the Black Forest." (Lyell, 1986, p. 3).

Wilson (1972, p. 367) considered that the Studer encounter was important and significant and devoted considerable space to its discussion. Leonard Horner (Fig. 3) was also writing at around this time and transmitted his enthusiasm for loess to Lyell: "How very extraordinary that Loess is? It has not been half attended to. I saw it today in great abundance, and at a considerable elevation between Muffendorf and the Rotherberg, and I found a bone in it about three inches long, and one and a half broad, which appears to me to be a portion of a rib of an animal as large as a horse." (Lyell, 1890, p. 271).

There was a limited amount of loess literature available to Lyell when he was writing the relevant section of vol. 3 of the 'Principles'. He acknowledged various people who had assisted in the preparation of the loess section and we assume that he was mostly referring to written material that he had consulted. In 1833, in the first printing of vol. 3 he acknowledged von Leonhard, Bronn, Boue, Voltz, Steininger, Merian, Rozet and Hibbert. In 1835 , in the $4^{\text {th }}$ edition, the list was expanded to include Noeggerath and von Meyer (Fig. 4). In 1837, for the $5^{\text {th }}$ edition, Horner was added. In 2015, it might be claimed that only von Leonhard, Bronn, Hibbert and Horner produced informative loess

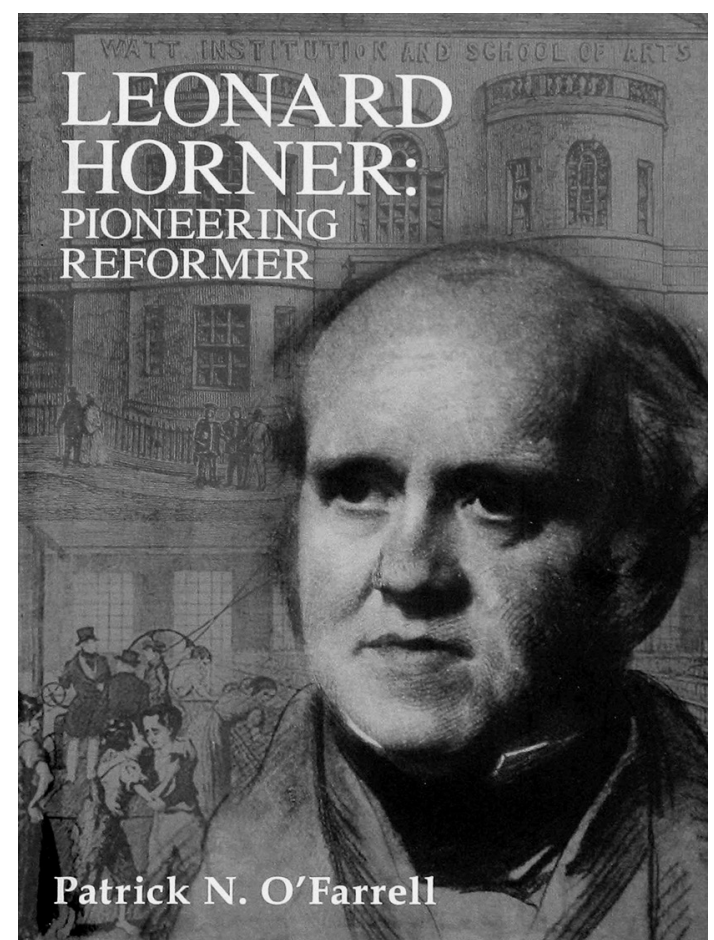

Fig. 3. Leonard Horner (1785-1864), father of Mary Horner/ Mrs Charles Lyell. Crayon drawing by Samuel Lawrence; used on the cover of O'Farrell (2010).

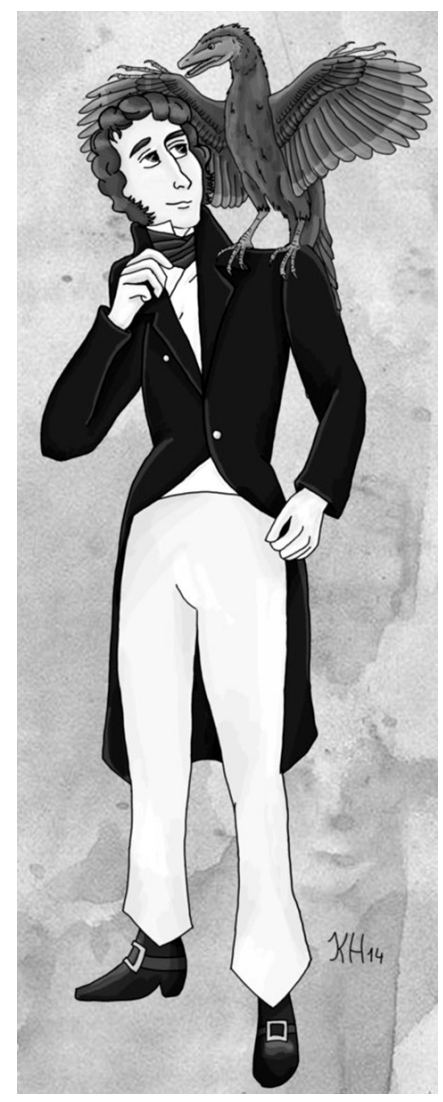

Fig. 4. Christian Erich Hermann von Meyer (1801-1869), awarded Wollaston Medal 1858. 
publications. Through his contact with Hibbert Lyell could have been fairly well informed about early loess publications. Hibbert was a great admirer of von Leonhard, in fact Hibbert (1832) is dedicated to von Leonhard. Hibbert reported the Von Leonhard writings in an almost word-for-word translation so that the original description was available in English in 1832. Also in 1832 it is fairly clear that Horner knew about (almost) all of the early German literature. He claimed (in 1833) that the best description of loess was that by Bronn (1830). The key Horner paper was not published until 1836 but it was read at the Geological Society in London in 1833. The Horner family only stayed at Bonn for about two years, 1831-1833, so the paper would have contained an assemblage of Horner's observations during his residence. This brought him into contact with various significant people. J.J. Noeggerath (Fig. 5) was professor of geology at Bonn and he and Horner made field trips together. Von Oeynhausen (Fig. 6) came to Bonn in 1831(and stayed ten years) and his work was cited by Horner but there is no direct evidence of a meeting.

Horner (1836) cited works by Voltz (1828), and Steininger (1821). Boue was considered important by Hibbert, largely because of his continent-wide ideas on flooding and inundation. "The latest tertiary deposit which appears to have charaterized the valley from Mayence to Basle has been properly considered by M. Boue as the product of a great

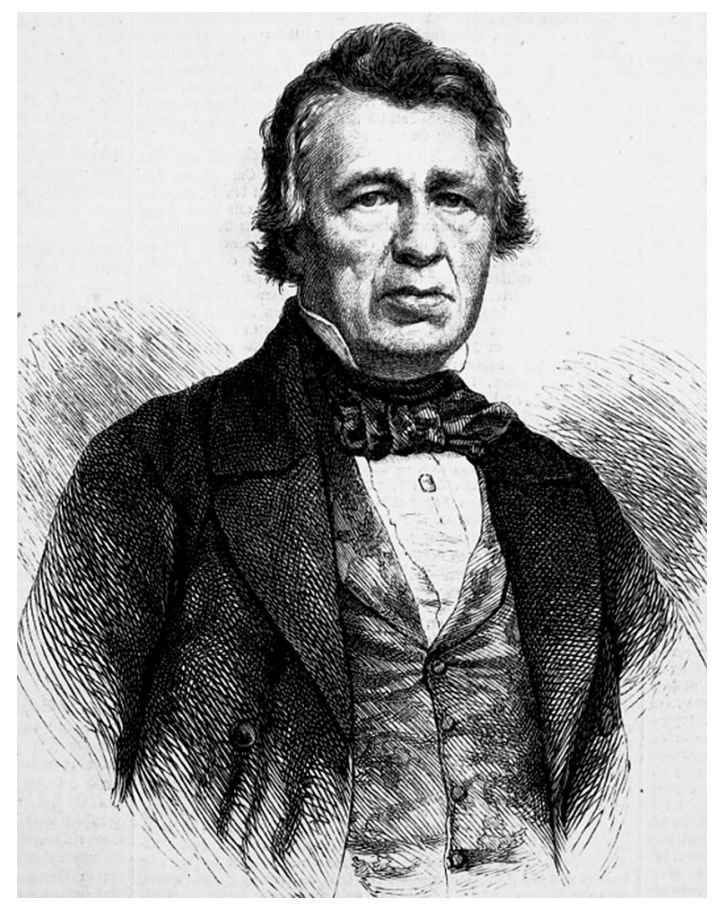

Fig. 5. J.J. Noeggerath (1767-1867), Professor of Geology at the University of Bonn.

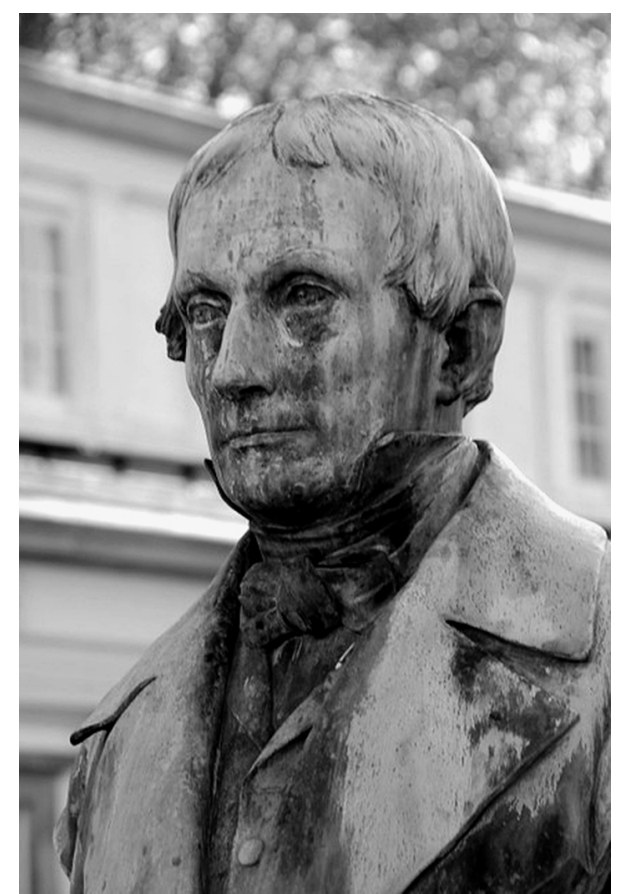

Fig. 6. Karl August Ludwig von Oeynhausen (1795-1865). The bust in front of the bath palace at Bad Oeynhausen.

fresh water sea that filled the whole basin of the Upper Rhine. It has been described under various names, of which the one most adopted is that of loess. M. Boue styles it an alluvial fresh water marl." (Hibbert, 1832, p. 185).

In 1835 the German Association for the Advancement of Science held its annual meeting in Bonn. Lyell was chair for one of the sessions, he shared the duties with von Buch, Buckland and Elie de Beaumont. In 1835 the complete 'Principles' had been available for two years and Lyell's reputation was growing. He had almost completed Lyell's loess list with the addition of von Meyer and Noeggerath, and he had published the Edinburgh paper in 1834. His major work on loess was essentially finished. Some 'loessic' people were at the Bonn meeting; note the presence of Noeggerath, von Meyer, von Oeynhausen and Berzelius. Horner was there but did not get mentioned by Lyell. The loess adventure possibly began in Bonn in 1831 and maybe ended there in 1835; encompassing two very useful visits to Heidelberg in the interim. Von Oeynhausen was there at the beginning, and the end.

\section{Lyell's inspirations}

The Lyell Loess List presents many interesting aspects. The complete list has eleven names: Bronn, von Leonhard, Boue, Voltz, Steininger, Merian, Rozet, Hibbert, Neoggerath, von Meyer 
and Horner. These names can be grouped in several ways. The first eight were on the original vol. 31833 list; the last three were added later. Von Leonhard and Bronn had several conversations and could provide substantial literature, and went with Lyell to see the loess. Boue was well known and Hibbert quotes him as describing the loess as an alluvial fresh water marl.

The 'Antiquity of Man', published in 1863, probably had some impact on loess studies. The loess section was small but Lyell took pains to relate loess to human activities. By being published in 1863 the book benefitted from the huge interest in geology and related topics caused by the publication of the 'Origin of Species' in 1859.

There may be a contribution by Murchison to early loess debates. He wrote : “... alluvial loam, called Loess, with terrestrial shells of existing species (of the genera Pupa, Helix, and Succinea mixed with bones of elephants of extinct species. The average thickness of this deposit is about 60 feet but at some places the thickness is much greater. It is greatly expanded near Krems and St. Polten, reaching occasionally the thickness of 140 feet, and having near these places, the exact appearance of the old alluvial hillocks in the valley of the Rhine, which have been described by M. Voltz." (Murchison, 1831, p. 402). This publication may have affected Lyell and his paper on loess (Lyell, 1834). It was published in the Edinburgh New Philosophical Journal (Jamieson's Journal). The Edinburgh jour-

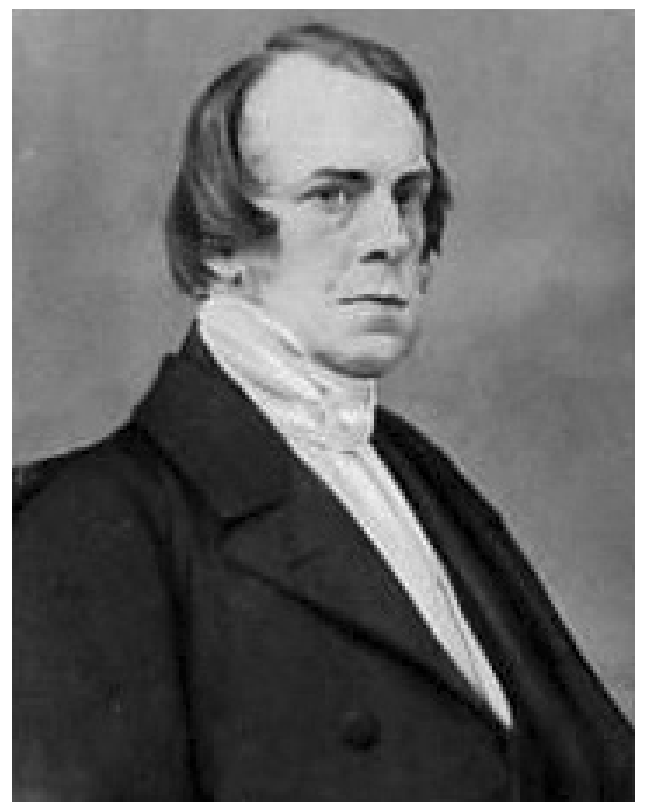

Fig. 7. Herr Hofrat Professor Dr Heinrich Georg Bronn (1800-1862) - so described by Gliboff (2008), who also called him 'Germany's most distinguished palaeontologist'. Awarded Wollaston medal 1861. nal had a widespread distribution; Lyell recorded seeing it on the desk of Berzelius when he was visiting this famous scientist; and the copy he observed was the one containing his loess paper.

In the 1830s the periodical literature was relatively undeveloped. Most of Lyell's references were to books. There are, for example, von Oeynhausen papers in the periodical literature which Lyell did not appear to be aware of. It might be that papers published in the German journals used the Old German typeface and this would have increased the problem of appreciation. Hertha, the geographical journal was published in Old German; the Old German text caused problems in unlikely places.

Heinrich Georg Bronn (1800-1862) (Fig. 7) requires some comments. He was the first on the Loess List of 1835; when Lyell was revising that section of vol. 3 and preparing to list people who had contributed to loess studies it was Bronn's name that came first to mind. Lyell talked to Bronn about loess, while standing in the loess country, looking at loess deposits: "In the deep gravel pits without the Manheim [sic] Gate of Heidelberg, loess is seen interstratified with gravel; and here more than one bed containing land and fresh-water shells, showing the effects of successive accumulation. I observed the same fact in the valley of the Lahn, north of Limburg, near the village of Elz; Professor Bronn informs me, that the calcareous concretions of the loess are sometimes arranged in horizontal layers, marking a difference in the carbonate of lime with which the sediment must have been charged at different periods." (Lyell, 1986, p. 4). Bronn fitted into Lyell's world. It was Bronn's (1830) description of loess that Horner (1836) used in his paper on the geology of Bonn. Bronn translated 'The Origin of Species' into German, and, with Haeckel, was largely responsible for the spread of knowledge about evolution in Germany (see Gliboff, 2008). Possibly there was some aspect of 'attraction of opposites'. Gliboff (2008) compared Bronn and Darwin, and the contrast was extreme. Perhaps, from the Bonn/Heidelberg viewpoint Lyell was a lot like Darwin. Gliboff (2008, p. 10) wrote: "Consider first Mr. Charles Robert Darwin. He never occupied a university chair or other professional position as a scholar or researcher, but was always a self-financed, amateur gentleman-naturalist. Darwin's German counterpart was the Herr Hofrat Professor Dr. Heinrich Georg Bronn. As the very name proclaims, he was no country gentleman, but a professional scholar and high-ranking civil servant."

When Bronn met Lyell in 1832 he was 32 years old, a young scholar, his great works were ahead of him. In 1837 he was promoted to full professor in 
both zoology and applied natural history. Gliboff, in discussing the works, does not mention Bronn (1830), the small book about Heidelberg, containing the discussions that the loess scholars value. Lyell was 35 years old at the time of meeting, was relatively well known because of vol. 1 published in 1830, and had just brought out vol. 2. He and Bronn appear to have related well to each other. In fact, in many ways Lyell was much more like Bronn than he was like his great friend Darwin. Lyell was a professional, making his living by writing about geology. His life revolved around geology and the activities of the Geological Society of London; he became Sir Charles Lyell Bt. FRS etc., had geological discussions with Queen Victoria and was buried in Westminster Abbey - all of which (apart from the burial part) Charles Darwin did not do.

\section{Timetable}

1830. The Principles of Geology, edition 1, volume 1, published by John Murray in London.

1830. Bronn Gaea Heidelbergensis published.

1831. In July Lyell goes on a short field trip to the Eifel; he also becomes engaged to Mary Horner. Conversations with Sam. Hibbert - loess is discussed.

1831. Somerville's Mechanism of the Heavens, published by John Murray.

1832. Principles, edition 1, volume 2 is published. Charles Lyell and Mary Horner are married in Bonn; they meet Bronn and von Leonhard in Heidelberg. Loess is examined.

1832. Hibbert Volcanoes of the Basin of Neuwied published.

1833. Principles, edition 1, volume 3 is published; it contains a section on loess. A tour of the Rhineland, examining loess - to be reported on in the Edinburgh paper.

1834. The paper on loess is published in the Edinburgh New Philosophical Journal (Jamieson's Journal): Lyell (1834) reprinted in Smalley (1975). Principles edition 3 in four volumes is published.

1835. Principles, edition 4 in four volumes is published. The loess section in vol. 4 is subsequently republished by Loess Letter (Lyell, 1986). The German Association for the Advancement of Science meets in Bonn.

\section{Final remarks}

Lyell was indefatigable. Lyell was possessed by a great enthusiasm for geology. He met and had discussions with von Meyer, Bronn, von Leonhard, Voltz, Studer, Agassiz and others. For a short period of time a portion of that enthusiasm was focused on loess. He was interested in loess; he liked to talk about loess, to go and see loess, to read about loess, and to write about loess. The writing about loess had the effect of spreading the word on this particular deposit to all parts of the world where the 'Principles' was distributed. The loess action was concentrated in the years 1831 to 1835 , and the geographical setting was the Rhine 'from Basle to Bonn'; the Rhine was the first of the great 'loess rivers'. There was a follow-up in 1863 when the 'Antiquity of Man', benefitting from the publication of 'The Origin of Species' in 1859, also transmitted some useful facts and opinions about loess.

\section{References}

Bailey, E., 1962. Charles Lyell. British Men of Science series. Thomas Nelson, London, 214 pp.

Bonney, T.G., 1895. Charles Lyell and Modern Geology. Cassell, London, $167 \mathrm{pp}$.

Boue, A., 1852. Erlauterungen uber die von mir im Loess des Rheinthales, im Jahre 1823 ausgefunden Menschenknochen. Sitzungberichte der Kaiserliche. Akad. Wiss. Math.-Naturwissenschsftliche Klasse, Wien, 8, 8890.

Bronn, H.G., 1830. Gaea Heidelbergensis, oder Mineralogische Beschriebung der Gegend von Heidelberg. Karl Gross, Heidelberg, 228 pp. (loess section reprinted in Loess Letter 67, April 2012, see www.loessletter. msu.edu).

Darwin, Ch., 1859. On the Origin of Species. John Murray, London, $502 \mathrm{pp}$.

Gliboff, S., 2008. H.G. Bronn, Ernst Haeckel, and the Origins of German Darwinism. MIT Press, Cambridge, 219 pp.

Hibbert, S., 1832. History of the Extinct Volcanos of the Basin of Neuwied, On the Lower Rhine. W.D. Laing, Edinburgh, $261 \mathrm{pp}$.

Horner, L., 1833. Geology of the environs of Bonn. Proceedings of the Geological Society of London 31, 467-470.

Horner, L., 1836. On the geology of the environs of Bonn. Transactions of the Geological Society of London 4, 433481.

Jovanovic, M., Gaudenyi, T., O’Hara-Dhand, K. \& Smalley, I.J., 2014. Karl Caesar von Leonhard (1779-1862), and the beginnings of loess research in the Rhine valley. Quaternary International 334-335, 4-9.

Lyell, C., 1833. Principles of Geology, 3 vols. John Murray, London.

Lyell, C., 1834. Observations on the loamy deposit called 'loess' of the Basin of the Rhine. Edinburgh New Philosophical Journal 17, 110-113 (reprinted in Smalley, 1975).

Lyell, C., 1863. The Geological Evidence of the Antiquity of Man. John Murray, London, 577 pp. 
Lyell, C., 1914. The Geological Evidence of the Antiquity of Man. Everyman's Library Edition, 700, 407 pp.

Lyell, C., 1986. Lyell on loess. Reprint of loess material from Principles 1835, ed. 4, v. 4, pp. 44-51. Loess Letter Supplement 8, 8 pp.

Lyell, K.M., 1881. Life, Letters and Journals of Sir Charles Lyell. John Murray, London, 386 pp. (Reprint Elibron Classics 2007).

Lyell, K.M., 1890. Memoir of Leonard Horner FRS FGS. Women's Printing Society, London, 2 vols., 376 \& 412 pp.

O'Farrell, P.N., 2010. Leonard Horner: Pioneering Reformer. Heriot-Watt University Press, Edinburgh, 378 pp.

Oeynhausen, C., Dechen, H. \& Delaroche, H., 1825. Geognostiche Umrisse der Rheinlander zwischen Basel und Mainz. G.D. Baedecker, Essen, 317 pp.

Sedgwick, A. \& Murchison, R.I., 1830. A sketch of the structure of the Eastern Alps; with sections through the newer formations on the northern flanks of the chain, and through the Tertiary deposits of Styria. Transactions of the Geological Society of London (ser. 2) 3, 301-420
Smalley, I.J.(ed.), 1975. Loess- Lithology and Genesis. Benchmark Papers in Geology 26. Dowden Hutchinson \& Ross, Stroudsburg, 476 pp.

Smalley, I.J., Gaudenyi, T. \& Jovanovic, M., 2015. Charles Lyell and the loess deposits of the Rhine valley. Quaternary International 372, 45-50.

Somerville, M., 1831. The Mechanism of the Heavens. John Murray, London, 345 pp.

Somerville, M., 1856. Physical Geography. John Murray, London, $432 \mathrm{pp}$.

Steininger, J., 1821. Neue Beitrage zur Gesichte der Rhenische Vulkane. Kupferberg, Mainz, 116 pp. (Electronic edition Koblenz-Landesbibliothekszentrum Rheinland-Pfalz 2010).

Voltz, P-L., 1828. Topographische Uebersicht der Mineralogie der beiden Rhein Departmente. C. Heitz, Strassburg, 317 pp.

Wilson, L.G., 1972. Charles Lyell - the years to 1841: The revolution in Geology. Yale University Press, New Haven, $553 \mathrm{pp}$.

Manuscript submitted 17 September 2015 Revision accepted 19 January 2016 